\title{
Jewish decisions about childhood vaccinations: The unification of medicine with religion
}

\author{
Akiva Turner
}

Correspondence: Aturner1@nova.edu

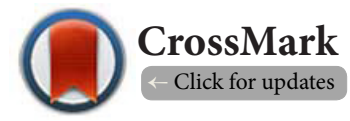

Associate Professor, Interim Director Ph.D. in Health Science Program, Nova Southeastern University, USA.

\begin{abstract}
Using Rabbinic rulings, religious texts, historical examples, and the scientific literature, this article explores the strong basis in Jewish law for an obligation to have children receive vaccinations against vaccine preventable diseases. In doing so, the article critiques the notion that medical information on vaccine risk and safety are strictly secular matters separate from religious ones. In Jewish law, medical matters of risk and safety are key to religious rulings regarding the acceptance of childhood vaccines and whether Jewish parents are obligated to have their children vaccinated. In other words, decisions regarding childhood vaccine requirements in Jewish law are religiously based upon the medical science.
\end{abstract}

Keywords: Childhood vaccinations, judaism, vaccine exemptions, jewish law

\section{Introduction}

"There can be no separation between the spheres of knowledge; science, acoustics, mathematics, religion and philosophy are all one entity. The formulas for their unification already exist; they are awaiting someone to merit their discovery." The Lubavitcher Rebbe [1].

The US Department of Health and Human Services (US DHHS) sets 10 year goals and objectives for health promotion and disease prevention [2]. The US DHHS goals and objectives curently in place are referred to as Healthy People 2020. Although the US DHHS has set the Healthy People 2020 target for most childhood vaccinations at $95 \%$ for kindergarten, actual vaccination requirements to enter school are set by state and local jurisdictions, not by the US DHHS or other federal agencies. Some state and local jurisdictions also allow medical, religious, and/ or philosophical based exemptions to these vaccine requirements [3]. Nationwide, exemption levels-including medical, religious and/philosophical exemptions--for children entering kindergarten in the 2014-2015 school year were at a median level of 1.7 percent. While this is low nationally, state by state exemption levels vary widely. Exemption levels during the 2014-2015 school year were as low as 0.1 percent in some states and as high as 6.5 percent in others [4]. According to Weiss [5], US parents who refuse to have their children vaccinated and request exemptions are more likely to reside in affluent, well-educated areas of major US cities, but some research, particularly in California and New York, has examined more closely the possible religious characteristics of parents who may be requesting and receiving certain types of exemptions. For example, Lai et al., [6] found that religious exemptions in New York state increased in both public $(0.17 \%$ to $0.29 \%)$ and private schools ( $0.63 \%$ to $1.35 \%$ ) between 2003 and 2012 . Among private schools these increases occurred in Catholic/ Eastern Orthodox, Protestant/Other Christian, Jewish and secular schools. All types of private schools, except Catholic/ Eastern Orthodox and Episcopal affiliates, were more likely to report exemptions when compared to public schools. In California, McNutt et al., [7] concluded that although an increase in non-medical exemptions was related to affluence, personal belief exemptions were found to be high among secular and non-Catholic Christian kindergartens but not among Roman Catholic, Jewish or Islamic kindergartens.

Although affluence seems to be a consistent finding in relation to vaccine refusal, the above studies do hint to some potential religious links. It is not the purpose of this article to review all religious vaccine beliefs and vaccine trends. Instead, this article will focus on orthodox Jewish beliefs that seem to support vaccination and the religious foundation of those beliefs. In the end, the article concludes that the medical arguments for and against vaccines are intertwined, albeit unified, with this community's religious based vaccination decisions.

\section{Review \\ The unity}

Non-Jewish sources and religions may sometimes separate the medical science of vaccines from religious perspectives 
Akiva Turner, Paediatrics and Health 2017,

http://www.hoajonline.com/journals/pdf/2052-935X-5-1.pdf

doi: $10.7243 / 2052-935 X-5-1$

toward them. For example, Wombwell et al., [8] explored generally why individuals and communities chose not to vaccinate their children for measles. Objections based upon religion were usually related to the use of aborted human fetus tissue used in the rubella component of the combined vaccine products and animal derived gelatins used in vaccine production. Wombwell et al., [8] then note that in some religious communities, concerns may be more "non-faith based" ones such as lack of safety and efficacy of the vaccination. In Judaism, however, safety, efficacy and risk are not "non-faith based" but are essential to making a religious determination about the permissibility to receive, or even a religious obligation to seek out, childhood vaccinations.

Judaism is based upon the written Torah ( 5 books of Moses) and the oral Torah (later codified), both of which are believed to have been given by G- $d$ to the Jews at Mount Sinai when the Hebrews became a Jewish nation. A body of codes and laws called halacha is derived from the written and oral Torah. As Greenberger [9] writes, "(H)alacha is the Jewish ethical and religious framework governing behavior in all facets of life. It is believed to be divinely ordained...."The word halacha comes from a Hebrew verb which means to walk, to go, or to journey. Halacha guides an observant Jew in how to eat, sleep, drink dress, conduct business, engage in various interpersonal and intimate relationships, as well as in the Jew's general conduct in all facets of life including seeking medical care.

In some cases, halacha can be very clear, but at other times, based upon the facts, a halachic decision may require the help of respected Rabbinic organizations, Beis Dins (Jewish Courts), or individual Rabbis to assist the Jew in knowing what is permissible and prohibited. Much has been written by such entities and individuals on the permissibility of vaccines. They base their opinions upon Jewish texts including the Torah, the Mishnah and Talmud, legal codes and writings, Responsa, and long standing customs [9].

In the past, as suggested by Wombwell et al. [8], some observant Jews may have rejected certain vaccines that contained nonkosher products such as pork gelatin. It is forbidden for a Jew to consume pork. However, the issue of pork components only applies to oral administration [10]. Israeli Orthodox Scholar Rabbi David Samson opined that "There is no prohibition in using medicines which contain forbidden ingredients if they are administered by injections, suppository, enema, medicated bandage, and the like, since they are not eaten" [11]. For example, a Beis Din in England determined that it was permissible to take a flu vaccine containing hydrolyzed pork gelatin as it is not eaten [11]. This is also the reason why the porcine valve and bioprosthetic heart valve ("pig valve") is permissible to save a life. Once the non-kosher objection is removed, halachic guidance focuses on safety, efficacy, and risk of disease in determining the halacha of vaccine administration, particularly for, but not limited to, children. The medical science is key to the religious determination.

\section{Historical perspective: small pox vaccine}

Discovered in the late $18^{\text {th }}$ century, the smallpox vaccine was the first successful and widely distributed vaccine. Prior to its development, 400,000 people died from smallpox each year, and one third of those who survived were rendered blind due to corneal infections [12]. In the vaccine's absence, doctors would inoculate healthy individuals with fluid from infected individuals. This was a risky approach given that some of these healthy individuals would die from the disease or infect others [12]. When asked whether it was permissible to receive such risky inoculations, Rabbi Abraham Nansich urged Jews to participate in these inoculations despite the risks. Rabbi Nanisch weighed the risks of the inoculation with the risks of contracting the disease without the inoculation. In the end Rabbi Nanisch determined that although one might not normally permit such a risk from an inoculation under halacha, in this case it was permissible since everyone was at a greater risk from a deadly outbreak [13].

Once the smallpox vaccine was discovered, some halachic authorities were then asked to rule whether it would be permissible to accept the vaccine. Though effective in preventing smallpox, the vaccine does carry some mild to severe life threatening risks. Rabbi Yisroel Lipschutz responded that despite the risk of death from the smallpox vaccine, one should still get vaccinated [14].

Rabbi Lipschutz, as well as other Rabbis, took into account the scientific knowledge of risk, efficacy, and safety in giving a religious based opinion. According to Steinberg [15], the halacha is about the risks versus the dangers. He points out that one can undertake the remote danger of the small pox vaccine to prevent the ultimate greater danger associated with the disease. In addition, all minimal risk treatments may be religiously obligatory, not just permissible, if the treatment prevents a more serious future danger.

\section{Childhood vaccines}

The Orthodox Union (OU) and the Rabbinical Council of America (RCA), two large contemporary orthodox Jewish Rabbinic organizations, strongly urge vaccines in general, including childhood vaccines. According to the OU [16] "Prayers must go hand in hand with availing oneself of medical science, including vaccination. There are halachic obligations to care for one's own health as well as to take measures to prevent harm and illness to others, and Jewish law defers to the consensus of medical experts in determining appropriate responses to illness and prevention. Therefore, the consensus of major poskim (halachic religious authorities) supports the vaccination of children to protect them from disease, to eradicate illness from the larger community through so-called herd immunity, and thus to protect others who may be vulnerable."

Rabbi Menachem Schneerson ("Lubavitcher Rebbe"), leader of the Lubavitcher Chassidic movement who physically passed away in 1994, would often receive letters from Jews around the world asking about certain medical treatments and how 
to proceed. Many of these letters and his responses have been preserved and published. The Lubavitcher Rebbe once received a letter questioning the use of the Salk polio vaccine. He responded, "The vaccine is used in many countries; in the United States almost all children are successfully vaccinated. Thus it is proper for you do so as well" [17]. In another letter responding to an Israeli writer, he wrote, "for many months now individuals here in the United States have been doing so, and this includes those who belong to the most G-d fearing and pious segments of the community. This is to say there is no question as to the kashrus [kosher status of the vaccine] and the like."Then after giving similar advice to another Israeli petitioner, he added, "Understandably, if there are inoculations that are produced by various drug-manufacturing companies, you should use the ones whose safety is tried and proven" [17]

Rabbi Eliashiv, a Haredi Israeli Rabbi who lived from 1910-2012, also ruled that since immunization of children is a normative practice throughout the world, parents should consent to immunizations regardless of concerns. According to Rabbi Eliashiv, not immunizing ones children would amount to negligence [18].

\section{Halachic sources}

Halachic opinions rely upon various religious sources when taking into account the state of the science and giving such strong advice. The strength of the halachic basis for childhood vaccines led one $20^{\text {th }}$ Century halachic authority, Rabbi Shlomo Zalman Auerbach, to advise that if there is a reasonable concern that not being vaccinated would be a danger and one can only get the vaccine on the Jewish Sabbath or would have to wait a few years for another chance, then immunizations would be permitted on the Sabbath [10]. On the Jewish Sabbath certain activities, including some involved in getting the vaccinations, are strictly prohibited, but according to Rabbi Auerbach one may perform these activities in the specific circumstances described above.

At a broad level, as alluded to in the OU statement, Judaism teaches that one cannot rely upon Divine intervention alone for protection and healing because one cannot be sure that one is worthy of such intervention. Moreover, the Torah advises that persons should "be careful and watch yourselves" and that persons should "greatly heed their souls" which is interpreted as a directive to avoid dangerous situations [13]. There is an additional fundamental Jewish concept, Pikuakh Nefesh (saving a life), that is central to Jewish thought and practice. Pikuakh Nefesh means that it is a mitzvah (obligation/ connection to the Divine) to save one's own or another's life, and with a few notable exceptions, one should do so even if it involves some other religiously prohibited act or activity.

In addition to saving one's life or the life of another from danger, the Torah also addresses preventive health. Moshe ben Maimon, the physician and Rabbi known as Maimonides or Rambam, lived from the $12^{\text {th }}$ to the beginning of the $13^{\text {th }}$ centuries. He wrote that one can only serve G-d if one en- joys health and well-being [19]. Rambam's message hints at preventative medicine as well as treatment. More recent and specific, the Lubavitcher Rebbe discussing inoculations wrote, "Preventive medicine has been employed by distinguished Jewish greats and leaders on a regular basis. Moreover, there is an explicit verse, 'No illness shall befall you, for I am G-d your healer' [which is to say] that preventive medicine is also a legitimate form of healing" [17].

Caring for the body in order to serve the Divine is not optional in Judaism. In Judaism, one's body is a loan from the Divine, and one is obligated to care for one's own physical health in order to serve the Divine. Given that one does not own one's body, one should not damage it and must take actions to protect it as well. Applying this obligation specifically to communicable diseases, Rabbi Moshe Isserles ("Rema") whose rulings are written in the code of Jewish Law, the Shulchan Aruch, ruled that when a plague breaks out in a city, inhabitants should try and flee the city to avoid infection and death [20].

As noted earlier it is a mitzvah under the concept of Pikuack Nefesh not only to save one's own life, but also to save the life of others, but there are more specific obligations in the Torah regarding protecting others as well. For example, in the written Torah, Jews are instructed that it is a religious obligation to build a guardrail around the roof of a newly built home lest someone fall [21]. This because a roof may serve the dual purpose as a porch, and in such a case, a railing would be necessary to protect others from falling. This guidance has been applied to many activities and behaviors beyond guardrails on roofs based upon its underlying presumption that one should do what is necessary to protect others. Even more directly, the Torah instructs one to not stand idly by the blood of your neighbor [22]. Anyone who can save a life and fails to do so violates this Torah commandment.

Notwithstanding the above Torah instructions, one writer has tried to find an even clearer basis in Torah that obligates one to others and the community in a way that one might be required to be vaccinated to help achieve communal or herd immunity. The Talmud addresses communal affairs and in one passage teaches that those who share a common courtyard can insist that all who share in this courtyard participate in expenses to build a wall, gate or door for protection and privacy [23]. Greenberger [9], though not a halachic authority, takes this passage of the Talmud and argues for a collective obligation to achieve communal or herd immunity.

\section{Parental obligations}

In addition to an obligation to protect one's own health and the health of others, Jewish religious texts also speak to specific parental obligations for the welfare of a child, some of which have been applied to vaccinations. As discussed earlier, when a plague breaks out in a city, inhabitants should try and flee the city to avoid infection and death [20]. Rabbi Yeshayah ha-Levi Horowitz ("Shelah") [24] points out that if a parent does not take ones child from the plagued city, the parent 
Akiva Turner, Paediatrics and Health 2017,

http://www.hoajonline.com/journals/pdf/2052-935X-5-1.pdf

doi: $10.7243 / 2052-935 X-5-1$

is responsible for the child's fate. In less urgent areas of life, parents are also encouraged to take preventive measures to protect their child's health and wellbeing. For example, the Talmud encourages parents to teach children to swim so if the children were to travel by boat, the children would be able to swim and survive should the boat sink [25].

These two cases have been applied to vaccines, but their application to vaccines is not precise [10]. Unlike teaching a child to swim or fleeing from a plague, vaccines may have more certain inherent risks of their own [10]. However, halacha permits the taking on of risks that most humans accept such as driving cars or crossing a street even though these activities have inherent risks of their own, and as already noted in the case of the small pox vaccine, one may take on an even greater risk to prevent an even larger risk of danger, particular if the risk taken is a widely accepted risk. This is the reason why the Rabbis emphasize in their opinions that vaccines are generally accepted and successfully used worldwide and in specific communities.

Thus far, the above discussion has revolved around whether a parent should voluntarily vaccinate a child. The question still remains if under halacha, exemptions should be allowed for school entry or should parents be mandated to vaccinate their children. Again, the religious analysis here is also intertwined with the state of the medical science. According to Rabbi Yosef Shalom Elyashi, since there is a medical consensus, parents are obligated to vaccinate their children and schools/camps may exclude children who are not vaccinated. He also ruled that parents have a right to demand that children coming into contact with their children be immunized [18].

Nevertheless, others seem to see it somewhat differently, but one should keep in mind that these apparent differences may be based upon the question and particular facts posed to the Rabbinic authorities and thus may not be a difference at all. In other words, rulings are fact specific. In any event, Rabbi Yehoshua Nwirth argues that even though Jewish law supports parents in vaccinating children, in the absence of a national legal mandate or an outbreak, schools should encourage vaccination but not force parents to vaccinate their children, and there is also at least one opinion that a parent cannot be compelled to have a child vaccinated even if the parent's refusal is based upon irrational fears [10].

In sum, based upon the basis of the medical science and knowledge of risks and dangers, halachic authorities seem to support that there is a religious obligation for children to receive widely accepted vaccines. However, it is less clear to what extent, if at all, under halacha that others can require parents to have their children vaccinated.

\section{Outbreaks}

Despite the halachic support for vaccines, there have been some reported outbreaks of vaccine preventable diseases, particularly measles, among a few orthodox Jewish communities. For example, in 2003 and 2004 measles outbreaks occurred in Jewish orthodox communities in Jerusalem. One outbreak began with an index case from Switzerland and the second one within what the authors describe as a "fringe" group. Immunization rates in the outbreak neighborhoods were $88.3 \%$ versus $90.3 \%$ in the non-outbreak neighborhoods. Most measles cases (91.5\%) occurred among the unvaccinated [26].

In 2013, a measles outbreak among an orthodox Jewish community in the Borough Park neighborhood of Brooklyn, New York accounted for 58 cases. No case occurred among persons who had documented measles vaccinations. Twenty-one percent of the cases were too young to be vaccinated (less than 12 months old) but $79 \%$ of the cases occurred in three families who had refused vaccinations. However, it should be noted that high vaccination rates in the community prevented extensive disease spread [27].

These outbreaks raise the question as to why a few, though far from most, orthodox Jews may refuse vaccines. Their reasons seem to be no different than the reasons put forth by other non-Jewish or secular vaccine refusers. According to Weiss [5], Jewish schools with low and high opt out rates for vaccinations range across denominational lines from community to Orthodox schools, and Grabenstein [10] concludes that Jewish vaccine decliners are more likely to cite concerns about vaccine safety.

In a March 30, 2014 on-line article at Collive.com, a website/news source servicing and frequented by the orthodox (Lubavitcher) Jewish Crown Heights community in Brooklyn, New York, Shuchat [28] presented the Lubavitcher Rebbe's perspective about having ones children vaccinated. In the comment section following the article, the small number of readers who challenged the author's points focused on vaccine risk, particularly the risk of autism. These individual objections are similar to those of others who are not orthodox Jews and refuse vaccines despite the fact that there is no evidence to link vaccines with autism and that claims of such a link have been discredited. There is no evidence that the vaccination for measles, mumps and rubella (MMR) is associated with autism and the original study claiming such an association was retracted in 2010 [29,30].

\section{Conclusion}

The reasons a small number of orthodox Jews may refuse childhood vaccinations are similar to those of secular or other religious groups and revolve around safety and efficacy. However, for orthodox Jews, the scientific considerations of safety and efficacy are not simply secular or scientific considerations but are intricate to and unified with the religious doctrine. Decisions by halachic authorities regarding the acceptance of, or obligation to receive, vaccines to prevent childhood diseases are religiously based upon religious law applied to the current state of medical science.

\section{Competing interests}

The author declares that he has no competing interests. 
Akiva Turner, Paediatrics and Health 2017,

Publication history

Editor: Alice Sterling Honig, Syracuse University Newyork, USA.

Received: 15-Dec-2016 Final Revised: 28-Jan-2017

Accepted: 28-Feb-2017 Published: 15-Mar-2017

\section{References}

1. Schneersohn MM. Mind over matter: the Lubavitcher Rebbe on science, technology, and medicine. Brooklyn, New York: F.R.E.E. Publishing House. 2003.

2. US Department of Health and Human Services (n.d.). Healthy people 2020 leading health indicators: a progress update. I Website

3. Orenstein WA and Hinman AR. The immunization system in the United States - the role of school immunization laws. Vaccine. 1999; 17 Suppl 3:S19-24. | Article | PubMed

4. Seither R, Calhoun K, Knighton CL, Mellerson J, Meador S, Tippins A, Greby SM and Dietz V. Vaccination Coverage Among Children in Kindergarten - United States, 2014-15 School Year. MMWR Morb Mortal Wkly Rep. 2015; 64:897-904. | Article | PubMed

5. Weiss A. At some day schools vaccination rates decline even as disease spreads. Jewish Telegraphic Agency. 2015. I Website

6. Lai YK, Nadeau J, McNutt LA and Shaw J. Variation in exemptions to school immunization requirements among New York State private and public schools. Vaccine. 2014; 32:7070-6. I Article | PubMed

7. McNutt LA, Desemone C, DeNicola E, El Chebib H, Nadeau JA, Bednarczyk RA and Shaw J. Affluence as a predictor of vaccine refusal and underimmunization in California private kindergartens. Vaccine. 2016; 34:1733-8. | Article | PubMed

8. Wombwell E, Fangman MT, Yoder AK and Spero DL. Religious barriers to measles vaccination. J Community Health. 2015; 40:597-604. | Article | PubMed

9. Greenberger C. Religion, Judaism, and the challenge of maintaining an adequately immunized population. Nurs Ethics. 2016. | Article | PubMed

10. Grabenstein JD. What the world's religions teach, applied to vaccines and immune globulins. Vaccine. 2013; 31:2011-23. I Article I PubMed

11. Price R. Why vaccinations are kosher and required. Jewish Journal. 2014. I Website

12. Gordis L. Epidemiology. Philadelphia: Elsevier Saunders. 2014.

13. Brody S. Does Jewish law mandate vaccinations? The Jerusalem Post. 2013. I Website

14. Tiferet Israel, Yoma 8:3.

15. Steinberg A. Encyclopedia of Jewish medical ethics. Jerusalem, Israel: Feldheim Publishers. 2003.

16. Orthodox Union. Statement on vaccinations from the OU and Rabbinical Council of America. 2015. I Website

17. Weinberger SB. Health in body, mind, and spirit. Brooklyn, New York: Silchos in English. 2007.

18. Tatz A. Dangerous disease and dangerous therapy in Jewish medical ethics: principles and practice. New Brunswick, New Jersey: Targum. 2013.

19. Mishneh Torah Hilchot Deot, 3, Eliyahu Touger Edition.

20. Shulchan Aruch, Yoreh De'ah 116:5.

21. Devarim 22:8, The Gutnick Edition.

22. Leviticus 19:16, The Gutnick Edition.

23. Tractate Baba Batra 2b, Shottstein Edition.

24. Commentaries of Ba'er Heitev and Mishnah Berurah on SA. Orach Chaim 576:7.

25. Tractate Kiddushin 29a, Shottstein Edition.

26. Stein-Zamir C, Zentner G, Abramson N, Shoob H, Aboudy Y, Shulman L and Mendelson E. Measles outbreaks affecting children in Jewish ultraorthodox communities in Jerusalem. Epidemiol Infect. 2008; 136:207-14. | Article | PubMed Abstract | PubMed FullText
27. Arciuolo RJ, Brantley T R, Asfaw MM, Jablonski JF, Giancotti FR, Rosen JB and Zucker JR. Notes from the field: measles outbreak among members of a religious community - Brooklyn, New York, MarchJune 2013. MMWR Morb Mortal Wkly Rep. 2013; 62:752-3. I Article I PubMed

28. Shuchat S. Anti-vaccine calls and halacha. Collive. 2014. I Website

29. Bazzano A, Zeldin A, Schuster E, Barrett C and Lehrer D. Vaccine-related beliefs and practices of parents of children with autism spectrum disorders. Am J Intellect Dev Disabil. 2012; 117:233-42. | Article | PubMed

30. Colaizzo GR. Misinformed parents, unvaccinated children and the fabricated vaccine-autism scare. Paediatrics and Health. 2016; 4:1. | Article

\section{Citation:}

Turner A. Jewish decisions about childhood vaccinations: The unification of medicine with religion. Paediatr Health. 2017; 5:1.

http://dx.doi.org/10.7243/2052-935X-5-1 